\title{
EXPLORING THE SAFE HUMAN MINDSET OF PRODUCTION LEADERS OF A PLATINUM MINE
}

\author{
N.J. Janse van Rensburg ${ }^{1}$, E.N. Barkhuizen ${ }^{2} \&$ K.J. Stanz ${ }^{2}$ \\ ${ }^{1}$ Department of Industrial Psychology and People Management \\ University of Johannesburg \\ ${ }^{2}$ Department of Human Resource Management \\ University of Pretoria \\ ${ }^{2}$ nicolene.barkhuizen@up.ac.za
}

\begin{abstract}
The aim of this research was to determine the safety mindset of managers, shift bosses, and miners as the production leaders in a South African platinum mine. The Safe Human Mindset Measuring Instrument (SHMI) was administered among a purposive selected sample of managers, shift bosses and miners $(N=106)$. Results showed significant differences between managers and miners in terms of relationship credibility, climate, trust, caring support, ownership, physical work environment, and attitude to safety. Significant differences were also found between managers and shift bosses in terms of trust and caring support, and between shift bosses and miners in terms of ownership. Practical implications are discussed and recommendations are made.
\end{abstract}

\section{OPSOMMING}

Die doel van die navorsing was om die houding van bestuurders, skofbestuurders en mynwerkers as produksieleiers in 'n Suid-Afrikaanse platinummyn ten opsigte van menslike veiligheid te bepaal. Die Veilige Menslike Houdingsinstrument is onder ' $n$ doelbewuste steekproef van bestuurders, skofbestuurders en mynwerkers afgeneem $(N=106)$. Die resultate het getoon dat betekenisvolle verskille bestaan tussen bestuurders en mynwerkers in terme van betroubare verhoudinge, klimaat, vertroue, ondersteuning, fisiese werksomgewing, en houding ten opsigte van veiligheid. Betekenisvolle verskille is ook gevind tussen bestuurders en skofbestuurders in terme van vertroue en ondersteuning, en tussen skofbestuurders en mynwerkers in terme van eienaarskap. Praktiese implikasies word bespreek en aanbevelings gemaak. 


\section{INTRODUCTION}

The mining industry in South Africa is in a process of transformation. The transformation can be ascribed to various influences such as the impact of health and safety legislation, the process of conversion of mineral rights, employment equity and black economic empowerment, and globalisation [1]. Central to the transformation process, and in the broader context of sustainable development, healthy and safe working conditions are among the first expectations in improving and maintaining production output in a safe manner [2]. However, it appears that the South African mining industry still experiences high fatality rates compared with the rest of the world [1]. With reference to an organisational context where safety is a concern, Hidley [3] states that leadership is one of the most crucial factors contributing to organisational success and safety efforts. Leaders should therefore promote a culture of safety in setting clear Occupational Health and Safety (OHS) expectations, aligning business and OHS goals, and establishing proactive risk management, communication, and feedback [2; 4].

According to Schutte [5], the mindset or motivational intent of a workforce is fundamentally shaped by relationship credibility, which leads to a specific climate (work life experience), resulting in a specific culture (behaviour in the company context). Relationship credibility embraces the trueness of the work relationship and the inherently caring character that bonds individuals as a team, and moulds or shapes the workforce mindset or motivational intent [6]. The key factors of trust, support, ownership, and respect are fundamental to relationship credibility [7]. Credible leadership should thus ensure sound relations on the shop floor by creating a specific climate and a compelling work atmosphere that results in a specific value-based culture and common beliefs. As all involved observe these, the desired safe behaviour is established [8]. Schutte [5] postulates that a lack of this credible leadership that ensures a compelling place to work, and the resultant absence of common values and beliefs, leads to a poor mindset or low motivation, and thus to a fatalistic approach. So leadership plays an important role in the behaviour of employees in the work situation, and contributes to minimising work-related incidents and injuries [9].

The effect and influence that leaders have on followers has been made clear in various studies. However, the study of leadership behaviour as a contributing factor in organisational safety is a relatively young science: the first reported studies were carried out in the 1980s [10]. Research indicates that unsafe behaviour contributes $87 \%$ or more to incidents and injuries (including fatalities) in a mine [9]. Besides the moral imperative to ensure mine safety [11], the negative attention that injuries and fatalities get from both society and the larger investment community is not in the industry's interest [1;9]. Thus, when leaders in an organisational safety context have a mindset conducive to safe production, their subordinates will develop a similar mindset, resulting in safe behaviour [12]. These authors further maintain that through participation in the day-to-day operations, both upper and middle level management get personally involved in safety activities in the organisation, and communicate an attitude of concern for safety to their employees. This in turn influences the degree to which employees comply with operating rules and safety practices. The aim of this research is thus to determine the safe human mindset of managers, shift bosses, and miners for the purpose of identifying significant differences between these three leadership levels, from which conclusions can be drawn and interventions recommended.

\section{THE SAFE MINDSET MODEL}

This research is based on the Safe Human Mindset Model developed by Schutte [6]. The model postulates that a workforce mindset is fundamentally shaped by credible relationships within a climate of competitiveness, where managers and employees contribute to the achievement of organisational goals, and where a sense of pride and accomplishment is established $[1 ; 2 ; 6 ; 4 ; 12]$. Within a safe working environment, the 
physical environment and safety intent are the two most important factors contributing to a climate conducive to safety. These are supported by a culture of common values and beliefs. A brief discussion of the model is presented in the next section.

\subsection{Relationship credibility}

According to Schutte [6], relationship credibility embraces the trueness of the work relationship and the inherently caring character that bonds individuals as a team, and moulds or shapes the workforce mindset or motivational intent. A well-developed, credible relationship is reflected in a mature and true work relationship that harmonises and synergises worker energy and effort constructively. This is conducive to safe, high quality, and productive behaviour that contributes to growing workforce responsibility and accountability [8; 13]. The key factors of trust, support, ownership, and respect are fundamental to relationship credibility.

\subsubsection{Trust}

Schutte [6] describes trust as the true nature of honesty - as openness, sincerity, reliability, and acceptance that make people feel relaxed and unguarded with each other. Trust is supported by rewards, allowing viewpoints, empowerment, feedback, honesty, sincerity, and courage. Maritz (2003) associates trust directly with a leadership attribute, and defines trust as a positive expectation that another party will not act opportunistically - in word, action, or decision - by violating any of the various dimensions of trust (integrity, honesty, openness, competence, consistency, and loyalty). Organisational success thus depends on interpersonal trust between leaders and subordinates [2; 14]. Trust promotes open communication and safe behaviour, and so reduces the number of accidents in the workplace [8].

\subsubsection{Caring support}

According to Hale [15], caring support originates from the concept of servant leadership. Parolini [16] associates four traits with caring leaders: active listening, understanding, acceptance, and empathy. These are all associated with emotional intelligence. Through caring for people and growing them, leaders gain legitimacy and followers follow willingly [17]. Schutte [6] describes support as the trueness and substance of practical assistance, guidance, coaching, care, kindness, and goodwill experienced by team members in the business. It is thus evident that support can be physical or emotional. Practical assistance with completing a job (for example, installing supports or coaching in the correct way to drill a hole in a stope) is a type of physical support. Listening is a critical form of emotional support. Emotional support is also associated with mentoring relationships [18]. Care, kindness, and goodwill display emotional support. Shared information, transparency, kindness, encouragement, unity, clear guidelines, and frontline visibility are all associated with caring support [6].

\subsubsection{Respect}

Schutte [6] describes respect as reflecting the perceptions of team members' honest, caring, and appreciative acceptance of the value of individual contributions and suggestions. Van Daalen \& Odendaal [19] identify respect as a fundamental value underlying any organisational development effort. Scott Geller [20] describes respect as the glue that holds people and organisations together. Respect is exercised in two forms: Briski [21] distinguishes between forced and voluntary respect. Forced respect results in rudimentary and regulatory respect. Rudimentary respect is granted when one feels obligated, and regulatory respect is shown through regulations (such as in the military between junior officers and senior officers). In the mining industry the shift boss is a legal appointee with safety responsibilities (as discussed earlier), commanding forced regulatory respect. Voluntary respect is associated with dignity, openness, approachability, confidentiality, courtesy, helpfulness, and friendliness [6].

\subsubsection{Ownership}

Ownership is the final factor relating to relationship credibility. According to Schutte [6], ownership reflects the perceived authority of decision-making, control, latitude, and independence of an individual or team at their level in the organisational hierarchy. Ownership is enhanced through management's willingness to make employees responsible 
for their decisions and actions, as well as backing (defending) subordinates when actions and decisions have been agreed upon. According to Hermanus [2], it appears that workers are not always engaged in ways that enable them to inform managers of specific OHS concerns, or to apply their experience and tacit knowledge of work and OHS hazards. Pfeffer \& Sutton [22] argue that organisational success relies on interdependence. They warn that internal competition destroys co-operation and works against interdependence. Innovation, productivity, and performance are the results of collective action, not just individual efforts and behaviour [23]. This is achieved when employees have 'bought into' the organisation. Schutte [6] associates information quality, truth, job security, creative scope, willingness to listen, and future prospects, with ownership.

\subsection{Work life experience (climate)}

The second aspect of the Safe Human Mindset Model developed by Schutte [6] addresses the aspects of work life experience and work environment that reflect the prevailing climate within the organisation. According to Schutte [6], workers encounter numerous experiences (sensations) in the organisation that reflect the prevailing climate. Barling, Kelloway \& Iverson [24] describe safety climate as a key intersection between organisational and psychological processes, and their relationship with safety. Safety climate helps to establish safety-related motivation in employees, and this motivation influences both the behaviour of individuals and the safety outcomes of the organisation [24; 25]. Studies conducted by Zohar \& Luria (as reported in [25]) found that safety climate influenced task performance and injury rates.

Safety climate, according to Schutte [6], consists of a workforce satisfaction component (attitude towards the job and organisation) and a work environment and supportive relationship component (consisting of the physical work environment and safety intent). A study conducted by Gyekye [26] confirmed a positive relationship between job satisfaction and safety climate, and workers were correspondingly more committed to safety policies and practices and registered lower incident rates. In examining leadership style, Ponder [27] examines democracy versus autocracy, participation versus direction, relationship versus task orientation, consideration as opposed to initiation, and action versus inaction. He concludes that leadership style affects employee job satisfaction, which determines attitudes and behaviour, all in the organisational safety context.

\subsection{Work environment and perceived supportive relationships}

\subsubsection{Physical work environment}

In the first instance, the physical work environment consists of safety-related dimensions and factors that can be directly observed and that, according to Schutte [6], are known as artefacts. These include risk assessments, personal protective equipment, posters, slogans, signs, and safety indicators in the workplace. Risk management is fundamental to improving health and safety, and involves the consideration of the organisation of work, ergonomics, the work environment, abnormal working situations, process safety, and the responsibility of employers to provide safe work systems and work environments [2]. These greatly complement a behavioural approach through continuous risk assessment, behaviour-based safety, rewards and recognition for accomplishments, and ongoing assessment of workplace conditions to improve ergonomics [12].

Two safety indicators are identified. The first is leading indicators, described as metric(s) used to drive and measure activities performed to prevent and control injury, damage, and loss [28]. Leading indicators are used proactively (as in the analysis of data to allow intervention before an incident - such as an unsafe act - occurs, as well as in perception survey results). Lagging indicators are reactive - for example, injury statistics. Lagging indicators (if used as an indicator of success) do more harm than good, since people are not empowered to take control of safety and develop a climate conducive to safety [28]. Mitchell [29] asserts that leading indicators are also used to monitor practices that could prevent incidents. A mix of both leading and lagging indicators is proposed to measure overall safety effectiveness and performance with the aim of continuously improving safety. 
Management is therefore required to inspect the work environment ergonomically using ventilation specialists, to evaluate working conditions using environmental specialists, and to use representative structures so that employees may contribute to health and safety [2]. The key is involvement of employees - and the use of praise and award (not just monetary reward) - to achieve health and safety performance.

\subsubsection{Safety intent}

Safety intent is described as the perceived state of supportive relationships in the work context [2]. Safety intent reflects the perception of an employee about management support, care, openness, and commitment towards employee involvement in workplace matters - including safety conditions, safety meetings, and safety-critical matters. Schutte [2] argues that this perception has a direct bearing on the mind-set of employee(s) and therefore contributes to their current behaviour. Trust amongst employees, communication, management support and involvement in safety matters, a friendly atmosphere, and being valued as people are associated with safety intent [2].

\subsubsection{Culture: Behaviour in company context}

From a safety perspective, Sutherland et al. [10] state that culture is a group phenomenon consisting of shared values and beliefs. Van Aardt [30] adds that the objectives and values subsystem should address safety through mission, vision, strategy, and objectives. People and groups represent attitudes, perceptions, motivation, communication, interpersonal relationships, human resources, and leadership. When people are not motivated through a culture or climate, negative attitudes and behaviours towards safety will be found.

In a study of safety culture and climate in the aviation industry, Wiegman et al. [10] define safety culture as an enduring characteristic of an organisation that is reflected in its consistent way of dealing with critical safety issues. Five global indicators of a safety culture are identified: the upper management levels' commitment to organisational safety through systems, training and practices; management involvement through participation of employees and communication with them; employee empowerment through delegation of authority or responsibility for safety; reward systems that include positive and negative rewards; and reporting systems that support a reporting culture [10]. The prevailing culture within an organisation is thus supported by the intensity of the leaders' values, just as the vision of the future influences followers positively [30]. Van Aardt [30] maintains that when the organisational values emphasise the importance of the management of occupational safety, it will be reflected in the behaviour of employees.

In summary, it is evident that managers and leaders have an important role to play in the organisational safety context through establishing credible relationships, creating a climate conducive to safe behaviour, and instilling a value and belief system that motivates a safe mindset in employees. Values in the organisational safety context influence behaviour, and leaders are responsible for establishing and displaying the values that are to be lived by all employees. Against this background, the main aim of this research is to determine the safe human mindset of managers, shift bosses, and miners. In the next section, the research design will be set out and the results of the research given. The article concludes with an overall discussion of the research results, and offers recommendations for managers and for future research into the safe human mindset.

\section{RESEARCH DESIGN}

\subsection{Research approach}

This study was a cross-sectional research design: data from more than one group was collected at a fixed point in time, and then compared in terms of the different leader groups. This design is ideally suited to the descriptive and predictive functions associated with correlation research [31]. 


\subsection{Research method}

\subsubsection{Participants}

The participants in the study were managers $\left(\mathrm{N}_{1}=18\right)$, shift bosses $\left(\mathrm{N}_{2}=28\right)$, and miners $\left(\mathrm{N}_{3}=60\right)$ of a South African platinum mine. The participants represented the total population, and a $100 \%$ response rate was obtained with all questionnaires usable for data analysis. In this sample, all participants were male, with $75 \%$ employed for three years or longer at the mine, and $55 \%$ aged 41 years or older.

\subsubsection{Measuring instrument}

The Safe Human Mindset Instrument (SHMI) [6] was used to measure the safe mindset of the target population. The SHMI consists of 60 items, and measures the constructs of relationship credibility (trust, caring support, respect, and ownership); climate (work satisfaction, physical work environment, and safety intent); and culture (values and beliefs). All items (statements) are scored on a 4-point Likert-type scale, which elicits responses from 'strongly disagree' (1) to 'strongly agree' (4). Acceptable internal consistencies were found for the subscales in previous studies ranging from 0.71 to 0.95 [6].

Demographic information gathered included years of service in the mine and age.

\subsubsection{Research procedure}

Permission to conduct the research was obtained from the General Manager. A motivation for the study was submitted and approved by the relevant managers. All participants were briefed and invited in writing to participate in the study. A schedule of sessions with all participants to complete the SHMI was prepared. All participants completed the SHMI, and the data gathered was captured on a spreadsheet using Microsoft Excel. Statistical analyses were completed by STATCON at the University of Johannesburg.

\subsubsection{Data analysis}

The statistical analysis was carried out with the SPSS program. The reliability and validity of the SHMI was determined by means of Cronbach alpha coefficients, as well as exploratory factor analysis. One-way analysis of variance (ANOVA) was used to determine the significance of differences between the safe mindset of managers, shift bosses, and miners. Scheffé post hoc tests were applied (subsequent to the ANOVA F-ratio) as a multiple comparisons test to compare the three leader groups with each other.

\section{RESULTS}

The psychometric properties of the SHMI were examined first. The Kolmogorov-Smirnov test was applied to test for the normality of the sample. The results are reported in Table 1.

The $p=.200, p>0.05$ result of the Kolmogorov-Smirnov test was non-significant, and consequently did not deviate from normality [32]. The normal frequency distribution facilitates the application of parametric tests [33]. No factor analysis could be performed because of the small sample size. The researchers therefore decided to use the theoretical scale and sub-scales of the SHMI as identified by Schutte [6]. The descriptive statistics and reliabilities of the Safe Health Mindset factor, as well as the sub-scales, are reported in Table 2.

Table 1: Test of normality: Kolmogorov-Smirnov (a)

\begin{tabular}{|l|c|c|c|c|c|c|}
\hline \multicolumn{1}{|c|}{ Tests of normality } \\
\hline & \multicolumn{2}{|c|}{ Kolmogorov-Smirnov (a) } & \multicolumn{3}{c|}{ Shapiro-Wilk } \\
\cline { 2 - 7 } & Statistic & df & Sig. & Statistic & df & Sig. \\
\hline Mean score & .067 & 106 & $.200\left(^{*}\right)$ & .984 & 106 & .244 \\
\hline
\end{tabular}


Table 2: Descriptive statistics and alpha coefficients of the SHMI

\begin{tabular}{lccccc}
\hline & Mean & $\begin{array}{c}\text { Std. } \\
\text { deviation }\end{array}$ & Skewness & Kurtosis & $\begin{array}{c}\text { Cronbach } \\
\text { Alpha }\end{array}$ \\
\hline $\begin{array}{l}\text { Safe Health Mindset } \\
\text { Subscales }\end{array}$ & 2.7907 & 16.91721 & -.375 & .311 & .887 \\
Relationship credibility & 2.8417 & 14.32425 & -.185 & -.335 & .884 \\
Climate & 2.7102 & 10.37746 & -.626 & -.067 & .864 \\
Culture & 2.8848 & 6.72042 & -.122 & -.190 & .696 \\
Trust & 2.7776 & 5.62024 & .084 & -.386 & .691 \\
Caring support & 2.8272 & 7.24346 & -.030 & -.406 & .804 \\
Ownership & 2.9520 & 5.40583 & -.632 & .661 & .776 \\
Physical environment & 3.0870 & 4.38396 & -.211 & -.374 & .744 \\
Safety intent & 2.7579 & 3.78250 & -.381 & -.305 & .730 \\
\hline
\end{tabular}

Next, an Anova was performed to assess the relationship between the three leadership levels and the combined variable of safe health mindset. The results are shown in Table 3.

Table 3: ANOVA F-ratio comparison of between subject effects for the three leader groups and dependent variable safe health mindset

\begin{tabular}{|c|c|c|c|c|c|c|c|c|}
\hline \multicolumn{9}{|c|}{ Dependent variable: Safe health mindset } \\
\hline Source & $\begin{array}{l}\text { Type III } \\
\text { sum of } \\
\text { squares }\end{array}$ & df & $\begin{array}{c}\text { Mean } \\
\text { square }\end{array}$ & $\mathbf{F}$ & Sig. & $\begin{array}{c}\text { Partial } \\
\text { eta } \\
\text { squared }\end{array}$ & $\mathbf{R}^{\mathbf{2}}$ & $\Delta \mathbf{R}^{2}$ \\
\hline $\begin{array}{c}\text { Corrected } \\
\text { model }\end{array}$ & $1.236(a)$ & 2 & .618 & 5.264 & .007 & .093 & .093 & .075 \\
\hline Intercept & 718.777 & 1 & 718.777 & 6124.536 & .000 & .983 & & \\
\hline Group & 1.236 & 2 & .618 & 5.264 & .007 & .093 & & \\
\hline Error & 12.088 & 103 & .117 & & & & & \\
\hline Total & 892.741 & 106 & & & & & & \\
\hline Corrected total & 13.324 & 105 & & & & & & \\
\hline
\end{tabular}

Table 3 shows that there are statistically significant differences between the leadership groups, based on safe health mindset $\left(F_{(2,103)}=5.264, p<0,01\right.$, partial $\left.\eta^{2}=0,093\right)$. Further post hoc tests revealed that managers reported significantly higher levels of safe health mindset than miners.

Anovas were then done to assess the relationship between the three leadership groups and the constructs of relationship credibility, climate, and culture. The results are reported in Table 4.

Table 4 shows that there are statistically significant differences between the management groups, based on relationship credibility $\left(F_{(2,103)}=6.79, p<0,01\right.$, partial $\left.\eta^{2}=0,117\right)$ and climate $\left(F_{(2,103)}=8.184, p<0,01\right.$, partial $\left.\eta^{2}=0,137\right)$. The Scheffé multiple comparisons post hoc test showed that managers scored significantly higher than miner supervisors in relationship credibility (mean difference $=0.373$ ) and climate (mean difference $=0.425$ ). Both effects are medium. No statistically significant differences were found between groups when questioned on culture. 
Table 4: ANOVA F-ratio comparison of between subject effects for the three leader groups and dependent variables (relationship credibility, climate, and culture)

\begin{tabular}{|c|c|c|c|c|c|c|c|c|}
\hline \multicolumn{9}{|c|}{ Dependent variable: Relationship credibility } \\
\hline Source & $\begin{array}{l}\text { Type III } \\
\text { sum of } \\
\text { squares }\end{array}$ & Df & $\begin{array}{c}\text { Mean } \\
\text { square }\end{array}$ & $\mathbf{F}$ & Sig. & $\begin{array}{l}\text { Partial } \\
\text { eta } \\
\text { squared }\end{array}$ & $\mathbf{R}^{\mathbf{2}}$ & $\Delta \mathbf{R}^{2}$ \\
\hline $\begin{array}{l}\text { Corrected } \\
\text { model }\end{array}$ & $1.965(a)$ & 2 & .983 & 6.793 & .002 & .117 & .117 & .099 \\
\hline Intercept & 708.270 & 1 & 708.270 & 4896.317 & .000 & .979 & & \\
\hline Group & 1.965 & 2 & .983 & 6.793 & .002 & .117 & & \\
\hline Error & 14.899 & 103 & .145 & & & & & \\
\hline Total & 874.600 & 106 & .983 & & & & & \\
\hline Corrected total & 16.865 & 105 & 708.270 & & & & & \\
\hline \multicolumn{9}{|c|}{ Dependent variable: Climate } \\
\hline $\begin{array}{l}\text { Corrected } \\
\text { model }\end{array}$ & $2.744(a)$ & 2 & 1.372 & 8.184 & .001 & .137 & .137 & .120 \\
\hline Intercept & 765.439 & 1 & 765.439 & 4566.241 & .000 & .978 & & \\
\hline Group & 2.744 & 2 & 1.372 & 8.184 & .001 & .137 & & \\
\hline Error & 17.266 & 103 & .168 & & & & & \\
\hline Total & 939.998 & 106 & & & & & & \\
\hline Corrected total & 20.010 & 105 & & & & & & \\
\hline \multicolumn{9}{|c|}{ Dependent variable: Culture } \\
\hline $\begin{array}{l}\text { Corrected } \\
\text { model }\end{array}$ & $.402(a)$ & 2 & .201 & 1.626 & .202 & .031 & .031 & .012 \\
\hline Intercept & 709.248 & 1 & 709.248 & 5736.637 & .000 & .982 & & \\
\hline Group & .402 & 2 & .201 & 1.626 & .202 & .031 & & \\
\hline Error & 12.734 & 103 & .124 & & & & & \\
\hline Total & 895.280 & 106 & .201 & & & & & \\
\hline Corrected total & 13.136 & 105 & 709.248 & & & & & \\
\hline
\end{tabular}

Next, Anovas were performed to assess the relationships between the three leadership groups and the sub-constructs of trust, caring support, ownership, physical environment, and safety intent. The results are reported in Table 5.

Table 5 shows that there are statistically significant differences between the management groups for relationship trust $(F(2,103)=4.491$, p $\square 0,01$, partial $\square=0,80)$, caring support $(F(2,103)=5,330 p \square 0,01$, partial $\square=0,094)$, ownership $(F(2,103)=8.864, p \square 0,01$, partial $\square 2=0,417$, physical environment $(F(2,103)=3.479$, $\mathrm{D} \square 0,01$, partial $\square=0,063)$, and safety intent $(F(2,103)=4.072$, $\square 0,01$, partial $\square=0,073)$. Further post hoc tests revealed that managers scored significantly higher in trust, caring support, ownership, physical work environment, and safety intent than miners. Managers also scored higher in trust and caring support than shift bosses. Shift bosses reported significantly higher levels of ownership than miners. The effects of trust, caring support, physical work environment, and safety intent are small, whereas the effect of ownership is medium.

A summary of the empirical results is presented in Table 6.

Table 6 shows that there are statistically significant differences between managers and shift bosses for climate and trust. Shift bosses and miners showed statically significant differences for caring support. Managers and miners showed statistically significant differences on all dimensions except culture. 
Table 5: ANOVA F-ratio comparison of between subject effects for the three management groups and dependent variables (trust, caring support, ownership, physical environment, and safety intent)

\begin{tabular}{|c|c|c|c|c|c|c|c|c|}
\hline \multicolumn{9}{|c|}{ Dependent variable: Trust } \\
\hline Source & $\begin{array}{l}\text { Type III } \\
\text { sum of } \\
\text { squares }\end{array}$ & df & $\begin{array}{l}\text { Mean } \\
\text { square }\end{array}$ & $\mathbf{F}$ & Sig. & $\begin{array}{c}\text { Partial } \\
\text { eta } \\
\text { squared }\end{array}$ & $\mathbf{R}^{2}$ & $\Delta \mathrm{R}^{2}$ \\
\hline $\begin{array}{c}\text { Corrected } \\
\text { model }\end{array}$ & $1.357(a)$ & 2 & .679 & 4.491 & .013 & .080 & .080 & .062 \\
\hline Intercept & 666.601 & 1 & 666.601 & 4411.315 & .000 & .977 & & \\
\hline Group & 1.357 & 2 & .679 & 4.491 & .013 & .080 & & \\
\hline Error & 15.565 & 103 & .151 & & & & & \\
\hline Total & 834.735 & 106 & & & & & & \\
\hline Corrected total & 16.922 & 105 & & & & & & \\
\hline \multicolumn{9}{|c|}{ Dependent variable: Caring support } \\
\hline $\begin{array}{c}\text { Corrected } \\
\text { model }\end{array}$ & $2.018(a)$ & 2 & 1.009 & 5.330 & .006 & .094 & .094 & .076 \\
\hline Intercept & 699.527 & 1 & 699.527 & 3694.651 & .000 & .973 & & \\
\hline Group & 2.018 & 2 & 1.009 & 5.330 & .006 & .094 & & \\
\hline Error & 19.502 & 103 & .189 & & & & & \\
\hline Total & 868.809 & 106 & & & & & & \\
\hline Corrected total & 21.520 & 105 & & & & & & \\
\hline \multicolumn{9}{|c|}{ Dependent variable: Ownership } \\
\hline $\begin{array}{l}\text { Corrected } \\
\text { model }\end{array}$ & $3.724(\mathrm{a})$ & 2 & 1.862 & 8.864 & .000 & .147 & .147 & .130 \\
\hline Intercept & 775.273 & 1 & 775.273 & 3690.913 & .000 & .973 & & \\
\hline Group & 3.724 & 2 & 1.862 & 8.864 & .000 & .147 & & \\
\hline Error & 21.635 & 103 & .210 & & & & & \\
\hline Total & 949.058 & 106 & & & & & & \\
\hline Corrected total & 25.359 & 105 & & & & & & \\
\hline \multicolumn{9}{|c|}{ Dependent variable: Physical environment } \\
\hline $\begin{array}{c}\text { Corrected } \\
\text { model }\end{array}$ & $1.577(\mathrm{a})$ & 2 & .788 & 3.479 & .035 & .063 & .063 & .045 \\
\hline Intercept & 827.439 & 1 & 827.439 & 3651.958 & .000 & .973 & & \\
\hline Group & 1.577 & 2 & .788 & 3.479 & .035 & .063 & & \\
\hline Error & 23.337 & 103 & .227 & & & & & \\
\hline Total & 1035.049 & 106 & & & & & & \\
\hline Corrected total & 24.914 & 105 & & & & & & \\
\hline \multicolumn{9}{|c|}{ Dependent variable: Safety intent } \\
\hline $\begin{array}{l}\text { Corrected } \\
\text { model }\end{array}$ & $3.057(a)$ & 2 & 1.529 & 4.072 & .020 & .073 & .073 & .055 \\
\hline Intercept & 675.451 & 1 & 675.451 & 1799.007 & .000 & .946 & & \\
\hline Group & 3.057 & 2 & 1.529 & 4.072 & .020 & .073 & & \\
\hline Error & 38.672 & 103 & .375 & & & & & \\
\hline Total & 847.944 & 106 & & & & & & \\
\hline Corrected total & 41.730 & 105 & & & & & & \\
\hline
\end{tabular}


Table 6: Summary of empirical results

\begin{tabular}{|c|c|c|c|c|c|c|c|c|c|}
\hline & $\underset{\text { 王 }}{\bar{n}}$ & 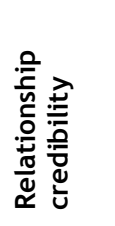 & 党 & $\frac{0}{3}$ & $\stackrel{\underline{\underline{n}}}{\underline{2}}$ & 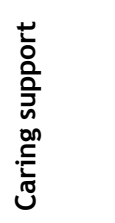 & 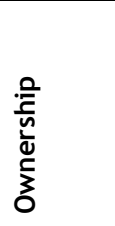 & 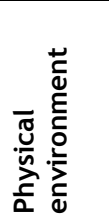 & 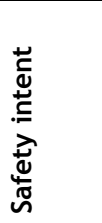 \\
\hline $\begin{array}{l}\text { Managers- } \\
\text { Shift } \\
\text { bosses }\end{array}$ & $\begin{array}{l}p=.081 \\
p>.05\end{array}$ & $\begin{array}{l}p=.106 \\
p>.05\end{array}$ & $\begin{array}{l}* \\
p=.037, \\
p<.05\end{array}$ & $\begin{array}{l}p=.596 \\
p>.05\end{array}$ & $\begin{array}{l}* \begin{array}{l}* \\
p=.04 \\
p<.05\end{array}\end{array}$ & $\begin{array}{l}p=.103 \\
p>.05\end{array}$ & $\begin{array}{l}p=.333 \\
p>.05\end{array}$ & $\begin{array}{l}p=.15 \\
p>.05\end{array}$ & $\begin{array}{l}p=.081, \\
p>.05\end{array}$ \\
\hline $\begin{array}{l}\text { Shift } \\
\text { bosses- } \\
\text { Miners }\end{array}$ & $\begin{array}{l}p=.388 \\
p>.05\end{array}$ & $\begin{array}{l}p=.346 \\
p>.05\end{array}$ & $\begin{array}{l}p=.053 \\
p>.05\end{array}$ & $\begin{array}{l}p=.758 \\
p>.05\end{array}$ & $\begin{array}{l}p=.999, \\
p>.05\end{array}$ & $\begin{array}{l}p=.615 \\
p>.05\end{array}$ & $\begin{array}{l}\text { * } \\
p=.038, \\
p<.05\end{array}$ & $\begin{array}{l}p=.506, \\
p>.05\end{array}$ & $\begin{array}{l}p=.388, \\
p>.05\end{array}$ \\
\hline $\begin{array}{l}\text { Managers- } \\
\text { Miners }\end{array}$ & $\begin{array}{l}* \\
p=.000 \\
p<.05\end{array}$ & $\begin{array}{l}\text { * } \\
p=.002, \\
p<.05\end{array}$ & $\begin{array}{l}\text { * } \\
p=.000, \\
p<.05\end{array}$ & $\begin{array}{l}p=.209 \\
p>.05\end{array}$ & $\begin{array}{l}* \\
p=.01 \\
p<.05\end{array}$ & $\begin{array}{l}\begin{array}{l}* \\
p=.006, \\
p<.05\end{array} \\
p=0\end{array}$ & $\begin{array}{l}\text { * } \\
p=.001, \\
p<.05\end{array}$ & $\begin{array}{l}\text { * } \\
p=.000 \\
p<.05\end{array}$ & $\begin{array}{l}\text { * } \\
p=.000 \\
p<.05\end{array}$ \\
\hline
\end{tabular}

\section{DISCUSSION AND CONCLUSION}

The aim of this research was to determine the safety mindset of managers, shift bosses, and miners in a South African platinum mine. The research identified the factors that influence and contribute to the safe mindset of the manager, shift boss, and miner leader levels in the organisation. The research further identified areas for development of the three leader levels in the organisation to progress to world-class organisation status for occupational health.

The combined results show that managers scored statistically significantly higher than miners on safety mindset, climate, culture, trust, caring support, ownership, physical work environment, and safety intent. The results of this study are in line with the findings of O'Dea \& Flin [34], who identified different responsibilities for safety at different leader levels in the organisation. Schutte [6] argues that relationship credibility embraces the trueness of a working relationship that bonds individuals as a team through a caring process. The empirical study of Singh [13] supports the importance of credible relationships. Building credible relationships is an emotionally intelligent leader trait. Singh [13] associates emotional intelligence with organisational learning ability, and states that emotionally intelligent leaders create credible relationships that significantly enhance performance, goodwill, and trust. An empirical study by Hamlin \& Sawyer [23] not only found that leaders needed to foster a sense of ownership in subordinates, but needed to develop themselves to take ownership. Failure to incorporate these new styles of management would lead to perceptions of their being ineffective as leaders. A study by Wills, Watson \& Biggs [35] found a correlation between the extent to which management provided support to employees and safe performance. The finding on trust is also important, as organisational success depends on trust between leaders and subordinates [2] and hence contributes to safe behaviour in the organisation [8].

The statistically significant difference for climate in the results between managers and shift bosses, as well as between managers and miners, leads to the conclusion that an organisational climate conducive to safe production has not been established in line with the expectations of management below managerial level (shift boss and lower). Clarke \& Ward [36] found in an empirical study that leadership influence, associated with a transformational style, mediated organisational climate. O'Dea et al. [34] also found that management attitude influenced the attitudes and behaviours of middle management, which in turn influenced relationships and styles of leadership down the organisational hierarchy. The various organisational leaders influence the organisational climate. Van Aardt's [30] empirical research found that when employees perceived organisational 
commitment to safety, their belief system about safety was greatly enhanced. Similarly, an empirical study by Larsson, Sjöberg, Vrbanjac, \& Björkman [37] found that indirect leadership, consisting of interaction down the line and role modelling, contributed to a culture of safety commitment and participation.

This research has some implications for managers. The development of credible relationships (consisting of trust, caring support, respect, and ownership), and influencing attitudes towards the job and organisation, and cultivating a values and belief system, falls within the ambit of leadership development. Ownership of safety (not specifically defined between shift boss and miner level in this study) has implications for the acceptance of safety and exercising responsibility for it. It is important to understand why such a problem exists; so managers should identify the appropriate systems and behaviours that would build ownership at these levels. Not only is the shift boss level a legal appointment under the relevant Act, but underdeveloped relations have consequences for employment relations in a unionised environment.

The shift boss level acts as a significant barrier between managers and miners, and may result in communication from management abut policies, practices, and procedures being inadequately filtered down the organisational hierarchy. This has implications for safety practices. Management should establish the desired behaviours at the various levels, and equip those leader levels with the appropriate skills. Action research, including joint problem solving, can elicit the required behaviours at the identified leader levels. Similarly, a care and growth process will ensure that means, ability, and accountability are established at the various leader levels, and supported with key performance indicator and performance management systems. Equipping leaders with coaching skills may also help to build credible relations. Current remuneration practices need to be adapted to support the newly-established accountabilities at the appropriate levels.

This study had some limitations. It was conducted in a single mine that is part of a group within a mining company. So the results cannot be generalised to other mines. Furthermore, the study was limited to three leader levels as groups in the mine, and presented some challenges in terms of the sample size obtained in this research. Other dynamics that could have an impact on the safe mindset of leaders - for instance, legislation - were omitted from this research.

For future research it is recommended that the safe human mindset of both leaders and workers be measured to gain a broader perspective on the safe human mindset in the context of individuals and teams. The researchers also recommend that the relationship between the corporate head office and the mine(s) concerning health and safety and a safe human mindset be studied. Finally, we recommend that the impact of the introduction of broad-based black economic empowerment, employment equity, and women in mining on occupational health and safety be investigated.

In conclusion, the study identifies the factors that influence and contribute to the safe mindset of the manager, shift boss, and miner leader levels in the organisation. The Safe Human Mindset Model provides a sound theoretical and management model which, when applied, suggests focus areas in which interventions can be planned and executed. The model is a diagnostic instrument that assists in managing safety, either re-actively or proactively, to eliminate incidents and fatalities. The identified areas for development refer to people (credible relationship), processes (work environment), and systems development, which require a focussed organisational development process. Meaningfully involving individual employees in job and safety related matters will reinforce a risk-minimising employee attitude and improve safety behaviour. It is proposed that leaders at the various levels be equipped with skills that include demonstration of complex tasks, advice, and instruction in a manner that would empower employees and reinforce trust, respect, dignity, and ownership. Establishing accountability, supported by an appropriate performance management system and reward scheme, would contribute to encouraging the identified required behaviours at the various leader levels. 


\section{ACKNOWLEDGEMENT}

A special word of thanks to Prof P.C. Schutte, who granted permission to use the Safe Human Mindset Instrument in this research.

\section{REFERENCES}

[1] Gallagher, N. 2009. Mining Health and Safety in South Africa. The African Business Journal. Retrieved September 28, 2010 from http://www.tabj.co.za/southern_africa/mining_health_ and_safety_in_south_africa.html

[2] Hermanus, M.S. 2007. Occupational health and safety in mining - status, new developments and concerns. The Journal of The South African Institute of Mining and Metallurgy, 107, 531-538.

[3] Hidley, J. 2004. Creating outstanding safety leadership. Understanding and leveraging leadership's role in safety. Perspectives in Behavioural Performance Improvement, January/February.

[4] Turner, N. \& Grey, G.C. 2009. Socially constructing safety. Human Relations, 62(9), 1259-1266.

[5] Schutte, P.C. 2004. Safe human culture development. Pro Human Inc. Johannesburg.

[6] Schutte, P.C. 1998. A success factor model to establish and manage harmonious and motivating environment, conducive to a committed and empowered work-force. Sustained health, safety and conformance. Safety in Mines Research Advisory Committee (Simrac). Project Nr GEN 511

[7] Maritz, D. 2003. Leadership and trust. In S.P. Robbins, A. Odendaal, \& G. Roodt, Organisational behaviour. Global and Southern African perspectives: South Africa. Cape Town: Pearson Education.

[8] Conchie, S.M., Donald, I.J. \& Taylor, P.J. 2006. Trust: Missing piece(s) in the safety puzzle. Risk Analysis, 25(5), 1097-1104.

[9] Heyneke, L. 2003. The contribution of personal and professional leadership qualities in minimising workplace related accidents. Unpublished Master's thesis. Rand Afrikaans University. Johannesburg.

[10] Sutherland, V., Makin, R.J. \& Cox, C.J. 2000. The management of safety. London: Sage Publications Ltd.

[11] Haase, C. 2003. Safety starts at the top. Mining Weekly. May 9-15.

[12] Wiegman, D.A., Zhang, H., Van Thaden, T., Sharma, G. \& Mitchell A. 2002. A synthesis of safety culture and safety climate research. Technical Report for Federal Aviation Administration. Atlantic City International Airport, N.J. June. Retrieved June 21, 2006 from htttp://www.humanfactors.uiuc.edu.

[13] Singh, K.S. 2007. Emotional intelligence and organisational leadership: A gender study in Indian context. International Journal of Indian Culture and Business Management, 1(1-2), 48-63.

[14] Whitener, E.M. 1998. Managers as initiators of trust: An exchange relationship framework for understanding managerial trustworthy behaviour. Academy of Management Review. July.

[15] Hale, J.R. 2004. A contextualised model for cross cultural leadership in West Africa. School of Leadership Studies, Regent University. Retrieved February 18, 2006 from http://www.regent.eduacat/globalproductions

[16] Parolini, J.L. 2004. Effective servant leadership: A model incorporating servant leadership and the competing values framework. School of Leadership Studies, Regent University.

[17] Schuitema, E. 2004. Leadership. The care and growth model. Kenilworth: Ampersand Press.

[18] Effective Practices Collection. 2003. Using ten techniques to sustain a successful mentoring relationship. The Resource Center. Retrieved July 3, 2007 from http://www.effective practices collection.com

[19] Van Daalen, D. \& Odendaal, A. 2003. Organisational change and stress management, In S.P. Robbins, A. Odendaal \& G. Roodt. Organisational behaviour. Global and Southern African perspectives: South Africa. Cape Town: Pearson Education.

[20] Scott Geller, E. \& Wiegand D.M. 2005. Exploring the role of personality in injury prevention. People Based Safety. Personal Safety. December.

[21] Briski, J. 2004. Earning respect. http:// CadetStuff.org.

[22] Pfeffer, J. \& Sutton, R.I. 1999. The knowing-doing gap. Stanford Graduate School of Business. November. Retrieved April 14, 2006 from http:/ /www.gsb.stanford.edu.htm.

[23] Hamlin, G. \& Sawyer, J. 2007. Developing effective leadership behaviors: The value of evidence based management. Business Leadership Review, 4(4). Retrieved March 3, 2008 from http://www.mbaworld.com/printb/rarticle/1046.htm.

[24] Barling, J., Kelloway, E. K. \& Iverson, R.D. 2003. High quality work, job satisfaction and occupational injuries. Journal of Applied Psychology, 88(2), 276-283.

[25] Newnam, S., Smith., M.A., Mason., C.M., Guthrie, D. \& Tay, R. 2006. Safety climate and driver safety at work: Integrating fleet management and OHS. Queensland University of Technology. Retrieved October 5, 2007 from http://www.carrsq.gut.edu.au. 
[26] Gyekye, S.A. 2005. Workers' perception of work place safety and job satisfaction. gyekye@mappi.helsinki.fi.

[27] Ponder, R.D. 2006. What's your leadership style? Retrieved May 2, 2007 from http: //smallbusiness.aol.com.

[28] BHP Billiton, 2006. A sustainable perspective. Retrieved July 2, 2007 from http://www.hsecreport.bhpbilliton.com.

[29] Mitchell, T. 2003. The safety monitor. BOC World Magazine. Retrieved September 28, 2007 from http: //www. bocworld.com.

[30] Van Aardt, M. 1995. Die verband tussen organisasie kultuur en houdings oor beroepsveiligheid in die mynbedryf. Ongepubliseerde doktorale proefskrif. Universiteit van Pretoria. Suid-Afrika.

[31] Shaughnessy, J.J. \& Zechmeister, E.B. 1997. Research methods in psychology (4 ${ }^{\text {th }}$ ed.). New York: McGraw-Hill.

[32] Field, A. 2005. Discovering statistics using SPSS. London: Sage Publications.

[33] Struwig, F.W. \& Stead, G.B. 2004. Planning, designing and reporting research. South Africa: Pearson Education.

[34] O'Dea A. \& Flin, R. 2003. The role of managerial leadership in determining workplace safety outcomes. Health and Safety Executive. University of Aberdeen. Research Report 044. United Kingdom.

[35] Wills, A.R., Watson, B. \& Biggs, H.C. 2006. Comparing safety climate factors as predictors of work-related driving behavior. Journal of Safety Research, 37(4), 375-383.

[36] Clarke, S. \& Ward, K. 2006. The role of leader influence tactics and safety climate in engaging employees' safety participation. Risk Analysis, 26(5), 1175-1185.

[37] Larsson, G., Sjöberg, M., Vrbanjac, A. \& Björkman, T. 2005. Indirect leadership in a military context: A quantitative study on how to do it. Leadership and Organisational Development Journal, 26(3), 215-227. 